\title{
Relationship of Progesterone, Bovine Pregnancy-Associated Glycoprotein-1 and Nitric Oxide with Late Embryonic and Early Fetal Mortalities in Dairy Cows
}

\author{
Aly KAREN ${ }^{1,2)}$, Árpád Csaba BAJCSY1), Rosa MINOIA ${ }^{3)}$, Rezső KOVÁCS ${ }^{1)}$, \\ Noelita Melo DE SOUSA ${ }^{4)}$, Jean-François BECKERS ${ }^{4)}$, János TIBOLD ${ }^{5)}$, István MÁDL ${ }^{5)}$ and \\ Ottó SZENCI ${ }^{1)}$ \\ 1)MTA-SZIE Large Animal Clinical Research Group, Faculty of Veterinary Science, Üllö-Dóra Major 2225, Hungary \\ 2) Department of Theriogenology, Faculty of Veterinary Medicine, Kafrelsheikh University, 33516 Kafrelsheikh, Egypt \\ ${ }^{3)}$ Department of Veterinary Medicine, Faculty of Veterinary Medicine, University of Bari "Aldo Moro", 70010 Valenzano \\ (Ba), Italy \\ 4)Laboratory of Animal Endocrinology and Reproduction, Faculty of Veterinary Medicine, Sart-Tilman 4000, Belgium \\ 5) Agroproduct Zrt, Páp, 8500, Hungary
}

\begin{abstract}
The aim of the present study was to determine the relationship of progesterone (P4), bovine pregnancy-associated glycoprotein-1 (bPAG-1) and nitric oxide (NO) levels with late embryonic (LEM; day 28 to day 42) and early fetal mortalities (EFM; > day 42 to day 56) in dairy cows. Transrectal ultrasonography (6-8 MHz) was performed in 100 Holstein-Friesian cows at days 28, 42 and 56 after artificial insemination (AI; day 0 ) to diagnose pregnancy and to monitor the fate of the embryo. After ultrasound scanning of each cow, a milk sample was collected for assessment of P4 by an ELISA test and a blood sample was collected for assessment of bPAG-1, by using a double-antibody radioimmunoassay, and serum NO metabolites (nitrate + nitrite). Based on ultrasonographic examinations and bPAG-1-RIA, 41 of 100 inseminated cows were confirmed pregnant at day 28 after AI. Nine cows suffered of LEM, and 6 cows suffered of EFM and the overall pregnancy loss rate was 36.6\% (15/41) between days 28 and 56 of pregnancy. By logistic regression analysis, there were no significant relationships between the level of P4 and bPAG-1 at day 28 after AI and the occurrence of LEM and EFM. Also, there were no significant relationships between the levels of P4 and bPAG-1 at day 42 and the occurrence of EFM. On the other hand, a significant relationship $(\mathrm{P}<0.05)$ was found between NO level at day 28 and the occurrence of LEM. In conclusion, measurement of the serum NO concentration at day 28 of pregnancy might help to predict the outcome of pregnancy by day 42 in dairy cows but further studies are needed to confirm this.
\end{abstract}

Key words: Bovine pregnancy associated glycoprotein-1, Dairy cow, Nitric oxide, Pregnancy loss, Progesterone

(J. Reprod. Dev. 60: 162-167, 2014)

$\mathbf{P}$ regnancy losses due to embryonic and fetal mortality are probably the major source of economic wastage in the modern dairy system [1]. Embryonic mortality has been subdivided into early embryonic mortality which occurs prior to maternal recognition of pregnancy (MRP; days 15-17 after breeding) and late embryonic mortality (LEM) which occurs between MRP and the beginning of the fetal period (day 42). Pregnancy losses that may occur from day 42 to calving are considered as fetal losses [2]. Although most pregnancy losses in dairy cows occur during the early embryonic period, the incidence of LEM and early fetal mortalities (EFM between days 42 to 90 of gestation) is increasing under conditions of intensive management [3].

Progesterone produced by the corpus luteum (CL) is essential for the establishment and maintenance of pregnancy. However, the

Received: March 26, 2013

Accepted: January 9, 2014

Published online in J-STAGE: February 15, 2014

(C)2014 by the Society for Reproduction and Development

Correspondence: A Karen (e-mail: alykaren@hotmail.com) relationship between progesterone (P4) level between days 24 and 42 and embryonic or fetal mortality in dairy cows is controversial among studies [4-7].

Bovine pregnancy-associated glycoproteins (bPAGs) and pregnancy-specific protein B (bPSPB) are mainly secreted by trophoblastic binucleate cells [8] and are released into the maternal circulation at the time of conceptus attachment to the endometrium (approximately day 25 in cows) [9]. Therefore, these glycoproteins have been used as a marker of pregnancy and feto-placental well-being in cattle [10]. Several studies have described the profile of bPAG-1 or bPSPB in cows with spontaneous or induced pregnancy loss [6, 10-13]; however, a few studies evaluated the use of bPAG-1 or bPSPB as a predictor of embryonic or fetal death $[5,14]$. The results of these studies indicated that plasma bPAG-1 or bPSPB at days 30-36 of gestation could be used as a predictive tool for pregnancy loss in dairy cows.

Nitric oxide (NO) is a gaseous free radical molecule and is produced by many cells through oxidation of L-arginine by enzyme nitric oxide synthase (NOS) [15]. Nitric oxide plays a key role in the functional and structural luteolysis of the corpus luteum in 
cattle [16]. Groebner et al. [17] demonstrated that a pronounced downregulation of NOS is required for successful early embryonic development, whereas messenger RNA levels for NOS declined markedly in the bovine endometrium during early pregnancy (day 18) when compared with those of cyclic cows. Furthermore, elevated concentrations of NO have been associated with early embryonic death. Culture with sodium nitroprusside dehydrate, a NO donor, inhibited development to the blastocyst stage of the bovine embryo [18]. Also, NO is a major endothelium-derived vasorelaxing factor and plays an important role in regulating placental fetal blood flows and thus transfer of nutrients and $\mathrm{O}_{2}$ from the dam to the fetus [19].

Since NO plays a key role in luteolysis and regulates the placental fetal blood flow, its blood concentration may change in cows suffering from embryonic or fetal mortalities. To our knowledge, the relationship between blood NO and pregnancy loss has not been investigated. Therefore the aim of the present study was to determine the relationship of P4, bPAG-1 and NO levels with LEM and EFM in dairy cows.

\section{Materials and Methods}

\section{Animals and management}

One-hundred Holstein-Friesian cows belonging to a dairy farm in Hungary were used in the present study from March to June 2010. The mean milk production for each cow during the study period was $34.3 \mathrm{~kg}$ per day (range: $17.9-52.9 \mathrm{~kg}$ ). The parity of the cows ranged between 1 and 8 with an average of $2.4 \pm 1.4$. The cows were between 55 and 475 days in milk with an average of $163 \pm$ 92.7 days. They had body condition scores at day 28 after AI of between 2.25 and 4.50 (average $3.35 \pm 0.44$, five-point scale) [20]. Number of services was 0 to 10 (average $1.91 \pm 2.39$ ). The cows were free from clinical endometritis, mastitis and laminitis. The animal protocols were approved by the local committee (Faculty Committee for Animal Experiments, Faculty of Veterinary Science, Szent Istvan University, Hungary).

According to the routine reproductive management, each nonpregnant cow with a mature corpus luteum was administered with $500 \mu \mathrm{g}$ of cloprostenol sodium ( $2 \mathrm{ml}$ of PGF Veyx ${ }^{\circledR}$ Forte A.U.V. inj, Veyx-Pharma GmbH, Schwarzenborn, Germany) intramuscularly. Three days later, all of these cows, not inseminated during the first and second day after PGF2 $\alpha$ treatment, were examined by rectal palpation by one of the inseminators; if a cow showed clinical signs (erected uterus, estrual discharge, and having an antral follicle) of estrus, it was inseminated and then $100 \mu \mathrm{g}$ of gonadorelin [6D-Phe] acetate ( $2 \mathrm{ml}$ of Gonavet Veyx ${ }^{\circledR}$, Veyx-Pharma $\mathrm{GmbH}$ ) was administered intramuscularly. The semen used for artificial insemination (AI) was chosen by the herd managers as part of the routine management of the herd. The day of AI was considered as day 0 for calculating the gestation period.

\section{Ultrasonographic examinations}

Transrectal ultrasonography (TRUS) was carried out by the same operator using a real-time B-mode ultrasound scanner (Falco Vet, Esaote/Pie Medical, Maastricht, The Netherlands) equipped with a 6-8 MHz linear endo-rectal transducer. Transrectal ultrasonography was performed for each cow at days 28, 42 and 56 after AI to diagnose pregnancy and to monitor the fate of the embryo. Positive diagnoses of pregnancy by transrectal ultrasonography depended on the detection of anechoic allantoic fluid and the embryo proper [21]. LEM and EFM were diagnosed when the embryo was detected without a heartbeat or when a previously observed embryo with a heartbeat was no longer visible during subsequent ultrasonographic examinations [21]. Ovaries were scanned for the type (with or without cavity), the number and the diameter of CLs. Pregnancies in which the number of corpora lutea exceeded the embryo number were recorded as pregnancies with additional CLs [22].

\section{Milk and blood sampling}

After ultrasound scanning, blood and milk samples were collected from each cow. After discarding the first 5 squirts of milk from each quarter, an equal amount of milk was collected from each quarter in a clean plastic tube $(10 \mathrm{ml})$ during morning milking. The collected milk was frozen at $-20 \mathrm{C}$ until assayed for progesterone (P4). Also, a blood sample was withdrawn from the tail vein of each cow using vacutainers (S-Monovette ${ }^{\circledR} 9 \mathrm{ml}$ Z, Sarstedt, Nümbrecht, Germany). Blood samples were kept in an ice box for a maximum 2 hours and then were centrifuged at $2000 \times g$ for 10 minutes. The collected serum was stored at $-20 \mathrm{C}$ until assayed for bPAG-1 and NO.

\section{Progesterone assay}

Progesterone concentrations in the whole milk were determined by using an ELISA test (Ovucheck ${ }^{\circledR}$ milk, Product \# C006, Biovet, Saint-Hyacinthe, QC, Canada). Progesterone concentrations were obtained from an absorbance microplate reader and washer (ELX800 and ELX50, BioTek U.S., Winooski, VT, USA). The intra- and interassay coefficients of variation were $5.10 \%$ and $8.15 \%$, respectively and the minimum detection limit of the assay was $1 \mathrm{ng} / \mathrm{ml}$.

\section{Bovine PAG-1 assay}

Serum concentrations of bPAG-1 were estimated by using a double-antibody radioimmunoassay (RIA-706) as previously described by Perenyi et al. [39]. Rabbit polyclonal antiserum AS\#706 was raised against co-purified caprine PAG $55 \mathrm{kDa}$ and PAG $62 \mathrm{kDa}$ (accession numbers P80935 and P80933). The minimum detection limit of the RIA-706 was $0.2 \mathrm{ng} / \mathrm{ml}$. The intra-assay and inter-assay coefficients of variation were 3.5 and $7.6 \%$, respectively. More details concerning RIA-706 validation (specificity, parallelism, accuracy) were previously reported by different authors [23, 24]. A bovine PAG-1 concentration of $0.8 \mathrm{ng} / \mathrm{ml}$ in the plasma [37] was taken as the cutoff point for diagnosing pregnancy.

\section{Nitric oxide measurements}

NO metabolites (nitrates + nitrites) were assayed colorimetrically by the Griess reaction as described by Green et al. [25]. Briefly, nitrates in serum were reduced to nitrites by incubation with nitrate reductase at room temperature for $3 \mathrm{~h}$. Thereafter, total nitrite concentrations were determined with the Griess reaction, by mixing equal volumes $(1 / 1)$ of reduced samples with Griess reagents ( $1 \%$ sulfanilamide in $5 \%$ phosphoric acid and $0.1 \%$ naphthalethylenediaminedihydrochloride in water). The samples were allowed to stand for 30 minutes and then read in a SpectraMax 250 microplate reader (BC-MDSMX250, Global Medical Instrumentation, Inc., Ramsey, MN, USA) at an 
Table 1. Mean ( \pm SD) days in milk, body condition score, parity, milk yield and number of previous inseminations in nonpregnant cows (NP), cows with ongoing pregnancy $(\mathrm{P})$ and in cows with late embryonic (LEM) or early fetal mortality (EFM)

\begin{tabular}{lcccc}
\hline & \multirow{2}{*}{$\begin{array}{c}\mathrm{NP} \\
(\mathrm{n}=59)\end{array}$} & $\begin{array}{c}\mathrm{P} \\
(\mathrm{n}=26)\end{array}$ & LEM $(\mathrm{n}=9)$ & EFM $(\mathrm{n}=6)$ \\
\hline Days in milk & $173.29 \pm 101.51$ & $156.8 \pm 74.50$ & $148 \pm 89.06$ & $103.83 \pm 70.10$ \\
Body condition score & $3.39 \pm 0.46$ & $3.33 \pm 0.42$ & $3.28 \pm 0.32$ & $3.25 \pm 0.52$ \\
Parity & $2.47 \pm 1.61$ & $1.80 \pm 0.71$ & $2.88 \pm 2.15$ & $3.17 \pm 1.72$ \\
Milk yield (kg/day) & $34.76 \pm 8.46$ & $33.59 \pm 11.15$ & $31.25 \pm 12.45$ & $37.31 \pm 5.60$ \\
Number of services & $1.91 \pm 2.39$ & $0.77 \pm 0.97$ & $1.81 \pm 2.31$ & $1.83 \pm 2.56$ \\
\hline
\end{tabular}

optical density of $550 \mathrm{~nm}\left(\mathrm{OD}_{550}\right)$. Nitrite concentrations were calculated by comparison with the $\mathrm{OD}_{550}$ of standard solutions of sodium nitrite prepared in saline solution.

\section{Statistical analyses}

Data were presented as means \pm SD. Days in Milk, body condition score, parity, milk yield, number of services and concentrations of P4, bPAG-1 and NO in nonpregnant cows, cows with normal pregnancy and cows that suffered from LEM or EFM were compared with ANOVA. A post hoc Turkey's test was used for pair-wise comparisons. Differences in the level of milk P4, bPAG-1 and NO over days of sampling $(28,42$ and 56) were evaluated by repeated measures ANOVA. The relationship between pregnancy losses (dependent variable) and P4, bPAG-1 and NO concentrations (continuous independent variable) at days 28 and 42 was evaluated by the logistic regression analysis [26] using SYSTAT 13. Binary logistic regression was used when the outcomes of pregnancy were ongoing pregnancy and pregnancy loss or EFM, while multinomial logistic regression was used when the outcomes of pregnancy were ongoing pregnancy, LEM and EFM. Values of P4, bPAG-1 and NO in cows with ongoing pregnancy were considered as the reference. An odds ratio significantly higher (or lower) than 1 implies an increased (or reduced) risk of pregnancy loss with each unit increase in the value of the independent variable. Differences were considered significant at $\mathrm{P}<0.05$.

\section{Results}

Based on TRUS examinations and the bPAG-RIA test, 41 of 100 inseminated cows were confirmed pregnant at day 28 after AI. Of those pregnant cows, three were diagnosed negative by TRUS at day 28 but had a bPAG-1 concentration higher than the threshold for diagnosing pregnancy. These 3 cows were between 90 and 252 days in milk at day 28 after AI. Of those 41 pregnant cows, 32 and 26 were diagnosed pregnant at days 42 and 56 after AI, respectively. Therefore, 9 cows suffered from LEM, 6 cows suffered from EFM, and the overall pregnancy loss rate was $36.6 \%$ (15/41) between days 28 and 56 of pregnancy. Five of 26 cows with normal pregnancy had an additional corpus luteum, while cows with pregnancy loss had no additional corpus luteum $(0 / 15)$. Twinning was detected only in a cow with normal pregnancy and therefore, the incidence of twinning in the present study was $2.4 \%$ (1/41).

No significant differences were observed in days in milk, body
Table 2. Mean $( \pm \mathrm{SD})$ milk progesterone concentrations in cows with ongoing pregnancy $(\mathrm{P})$ and in cows with late embryonic (LEM) or early fetal mortality (EFM)

\begin{tabular}{ccrr}
\hline & \multicolumn{2}{c}{ Progesterone concentrations $(\mathrm{ng} / \mathrm{ml})$} \\
\cline { 2 - 4 } Days after AI & $\mathrm{P}$ & \multicolumn{2}{c}{ Pregnancy losses } \\
\cline { 2 - 4 } & $(\mathrm{n}=26)$ & \multicolumn{1}{c}{ LEM $(\mathrm{n}=9)$} & \multicolumn{1}{c}{ EFM $(\mathrm{n}=6)$} \\
\hline 28 & $24.88 \pm 7.01^{\mathrm{aA}}$ & $23.83 \pm 3.69^{\mathrm{aA}}$ & $30.14 \pm 7.67^{\mathrm{aA}}$ \\
42 & $23.91 \pm 5.42^{\mathrm{aA}}$ & $6.81 \pm 3.42^{\mathrm{bB}}$ & $21.00 \pm 6.82^{\mathrm{aA}}$ \\
56 & $26.48 \pm 6.48^{\mathrm{aA}}$ & $12.55 \pm 7.75^{\mathrm{bB}}$ & $7.65 \pm 7.33^{\mathrm{bB}}$ \\
\hline
\end{tabular}

a,b. Data within the same row are significantly different $(\mathrm{P}<0.0001)$.

A,B. Data within the same column are significantly different $(\mathrm{P}<0.01)$.

condition score at day 28 after AI, parity, milk yield and number of previous AIs among cows with normal pregnancy, cows with LEM and EFM and nonpregnant cows (Table 1).

No significant differences in the levels of P4 were observed among cows with normal pregnancy and those with either LEM or EFM. In cows with LEM, $\mathrm{P} 4$ levels decreased significantly $(\mathrm{P}<0.01)$ at days 42 and 56. Also, in cows with EFM, a significant $(\mathrm{P}<0.01)$ decrease in the level of P4 was observed at day 56 (Table 2). There was no relationship between the level of P4 at day 28 after AI and the occurrence of LEM and EFM. Also, there was no relationship between the level of P4 at day 42 and the occurrence of EFM (Table 5). Progesterone concentrations in pregnant cows that had additional CLs were significantly higher $(29.78 \pm 5.58$ vs. $24.16 \pm 5.63 \mathrm{ng} / \mathrm{ml}$, $\mathrm{P}<0.005$ ) than those in cows having a single CL. However, pregnancy loss between days 28 and 56 was nonsignificantly higher in cows with a single CL compared with that in cows with two CLs (15/26 vs. $0 / 5, \mathrm{P}=0.14)$.

Concerning bPAG-1, a nonsignificant difference was observed at day 28 among cows with normal pregnancy and in those either with LEM and EFM. In cows with LEM, a significant $(\mathrm{P}<0.01 ; \mathrm{P}<0.05)$ decrease in the level of bPAG-1 was observed at days 42 and 56 after AI. Also in cows with EFM, a significant $(\mathrm{P}<0.05)$ decrease in the level of bPAG-1 was observed at day 56 after AI (Table 3). There was no significant relationship between level of bPAG-1 at day 28 and the occurrence of LEM and EFM. Also, there was no significant relationship between level of bPAG-1 at day 42 and the occurrence of EFM (Table 5).

Concerning the nitric oxide, a significant difference in its level was observed at day 28 between cows with LEM and cows with normal 
Table 3. Mean ( \pm SD) of bovine pregnancy-associated glycoprotein-1 (bPAG-1) concentrations in nonpregnant cows, cows with ongoing pregnancy $(\mathrm{P})$ and cows with late embryonic (LEM) or early fetal mortality (EFM)

\begin{tabular}{ccccc}
\hline & \multicolumn{3}{c}{ PAG concentrations (ng/ml) } \\
\cline { 2 - 5 } $\begin{array}{c}\text { Days after } \\
\text { AI }\end{array}$ & \multirow{2}{*}{$\begin{array}{c}\text { NP } \\
(\mathrm{n}=59)\end{array}$} & $\begin{array}{c}\mathrm{P} \\
(\mathrm{n}=26)\end{array}$ & \multicolumn{2}{c}{ Pregnancy losses } \\
\cline { 4 - 5 } & & LEM $(\mathrm{n}=9)$ & EFM $(\mathrm{n}=6)$ \\
\hline 28 & $0.25 \pm 0.10^{\mathrm{a}, \mathrm{A}}$ & $3.73 \pm 2.12^{\mathrm{b}, \mathrm{A}}$ & $3.32 \pm 2.17^{\mathrm{b}, \mathrm{A}}$ & $4.42 \pm 2.01^{\mathrm{b}, \mathrm{A}}$ \\
42 & $0.25 \pm 0.12^{\mathrm{a}, \mathrm{A}}$ & $7.18 \pm 2.88^{\mathrm{b}, \mathrm{B}}$ & $1.01 \pm 0.62^{\mathrm{a}, \mathrm{B}}$ & $5.52 \pm 3.92^{\mathrm{b}, \mathrm{A}}$ \\
56 & $0.28 \pm 0.24^{\mathrm{a}, \mathrm{A}}$ & $8.02 \pm 5.32^{\mathrm{b}, \mathrm{B}}$ & $0.46 \pm 0.19^{\mathrm{a}, \mathrm{C}}$ & $1.41 \pm 1.18^{\mathrm{a}, \mathrm{C}}$ \\
\hline
\end{tabular}

a,b. Data within the same row are significantly different $(\mathrm{P}<0.0001)$.

A,B. Data within the same column are significantly different $(\mathrm{P}<0.01)$.

B,C Data within the same column are significantly different $(\mathrm{P}<0.05)$.
Table 4. Mean ( \pm SD) serum nitric oxide (NO) concentrations in nonpregnant cows, cows with ongoing pregnancy $(\mathrm{P})$ and cows with late embryonic (LEM) or early fetal mortality (EFM)

\begin{tabular}{ccccc}
\hline & \multicolumn{4}{c}{$\mathrm{NO}(\mu \mathrm{M} / \mathrm{ml})$} \\
\cline { 2 - 5 } $\begin{array}{c}\text { Days after } \\
\text { AI }\end{array}$ & $\mathrm{NP}$ & $\mathrm{P}$ & \multicolumn{2}{c}{ Pregnancy losses } \\
\cline { 3 - 5 } \cline { 3 - 5 } & $(\mathrm{n}=59)$ & $(\mathrm{n}=26)$ & LEM $(\mathrm{n}=9)$ & EFM $(\mathrm{n}=6)$ \\
\hline 28 & $10.47 \pm 2.93^{\mathrm{a}}$ & $9.88 \pm 3.21^{\mathrm{a}}$ & $13.55 \pm 4.59^{\mathrm{b}, \mathrm{A}}$ & $9.83 \pm 2.94^{\mathrm{a}}$ \\
42 & $10.35 \pm 3.83$ & $11.14 \pm 3.81$ & $10.41 \pm 2.11^{\mathrm{B}}$ & $9.98 \pm 4.20$ \\
56 & $9.49 \pm 3.40$ & $9.69 \pm 3.59$ & $9.67 \pm 2.90^{\mathrm{B}}$ & $9.74 \pm 1.39$ \\
\hline
\end{tabular}

a,b. Data within the same row are significantly different $(\mathrm{P}<0.05)$.

A,B. Data within the same column are significantly different $(\mathrm{P}<0.05)$.

Table 5. Odds ratio of serum pregnancy-associated glycoprotein-1 (bPAG-1) and milk progesterone (P4) concentrations at days 28 and 42 in the logistic regression model for late embryonic (LEM) and early fetal mortality (EFM) in dairy cows

\begin{tabular}{|c|c|c|c|c|c|c|c|}
\hline \multirow{2}{*}{ Variable } & \multirow{2}{*}{ Days of pregnancy } & \multirow{2}{*}{ Outcome of pregnancy } & \multirow{2}{*}{$\mathrm{n}$} & \multirow{2}{*}{ Odds ratio } & \multicolumn{2}{|c|}{$95 \%$ Confidence intervals } & \multirow{2}{*}{$\mathrm{P}$} \\
\hline & & & & & Low & High & \\
\hline \multirow[t]{4}{*}{$\mathrm{P} 4$} & 28 & Ongoing pregnancy & 26 & Reference & & & \\
\hline & & Pregnancy loss (LEM and EFM) & 15 & 1.03 & 0.94 & 1.38 & 0.49 \\
\hline & 42 & Ongoing pregnancy & 26 & Reference & & & \\
\hline & & EFM & 6 & 0.69 & 0.72 & 1.05 & 0.14 \\
\hline \multirow[t]{4}{*}{ bPAG-1 } & 28 & Ongoing pregnancy & 26 & Reference & & & \\
\hline & & Pregnancy loss (LEM and EFM) & 15 & 1.01 & 0.74 & 1.39 & 0.94 \\
\hline & 42 & Ongoing pregnancy & 26 & Reference & & & \\
\hline & & EFM & 6 & 0.82 & 0.58 & 1.15 & 0.24 \\
\hline
\end{tabular}

Table 6. Odds ratio of serum nitric oxide (NO) concentrations at days 28 and 42 in the logistic regression model for late embryonic (LEM) and early fetal mortality (EFM) in dairy cows

\begin{tabular}{clccccc}
\hline \multirow{2}{*}{ Variable } & Outcome of pregnancy & $\mathrm{n}$ & Odds ratio & \multicolumn{2}{c}{$95 \%$ Confidence intervals } & \multirow{2}{*}{ P } \\
& & & & Low & High & \\
\hline NO (Day 28) & Ongoing pregnancy & 26 & Reference & & & \\
& LEM & 9 & $1.32^{*}$ & 1.04 & 1.69 & 0.03 \\
& EFM & 6 & 0.99 & 0.75 & 1.32 & 0.97 \\
\hline NO (Day 42) & Ongoing pregnancy & 26 & Reference & & & \\
& EFM & 6 & 0.91 & 0.7 & 1.2 & 0.51 \\
\hline
\end{tabular}

* Each $1 \mu \mathrm{M} / \mathrm{ml}$ increase in the level of $\mathrm{NO}$ compared with the mean level in cows with ongoing pregnancy increased the risk of LEM by a factor of 1.3 .

pregnancy and nonpregnant cows (Table 4). A significant relationship $(\mathrm{P}<0.05)$ was found between NO level at day 28 and the occurrence of LEM. At Day 28 of gestation, each $1 \mu \mathrm{M} / \mathrm{ml}$ increase in the level of NO compared with the mean level in cows with ongoing pregnancy increased the risk of LEM by a factor of 1.3 (Tables 4 and 6). The level of NO was significantly $(\mathrm{P}<0.05)$ decreased at day 42 in cows suffered from LEM. There was no significant difference in the level of NO between cows with ongoing pregnancy and nonpregnant cows throughout the days of sampling (Table 4).

\section{Discussion}

The pregnancy loss rate between days 28 and 56 after AI in the present study was $36.6 \%(15 / 41)$. Sixty percent $(9 / 15)$ of these losses were attributed to LEM and $40 \%(6 / 15)$ were attributed to EFM. The pregnancy loss rate between days 28 and 56 of pregnancy in the present study $(36.6 \%)$ is higher than the range $(11 \%$ to $\sim 30 \%)$ reported in other studies during the comparable range of days of pregnancy [14, 21, 27-32]. The difference in the rate of pregnancy loss between our study and the other studies might be attributed to the methods used for diagnosing pregnancy loss. In our study, we 
combined TRUS and the PAG test at day 28 for diagnosing pregnancy, whereas the accuracy of TRUS at that day for detecting pregnant cows has not reached $100 \%$ [21]. This explanation is confirmed by the lower pregnancy loss $(29.2 \%$; 12/41) when the ultrasound was used alone in our study for diagnosing pregnancy at day 28 after AI.

In the present study, there were no associations between milk P4 concentrations at day 28 or day 42 and the occurrence of pregnancy losses between days 28 and 56 of gestation. Similar results were reported in other studies that did not find a significant relationship between P4 level at day 30 [6], day 35 [7] or day 42 [5] and the occurrence of pregnancy losses in dairy cows. In contrast, Starbuck et al. [4] reported a significant relationship between P4 level during week 5 and the occurrence of pregnancy losses up to week 7 of gestation. In the latter study, the milk production of cows was not mentioned and it might have been higher than that of the cows in our study. Cows producing more milk may be more likely to have suboptimal concentrations of P4 [7]. The milk progesterone concentrations reported in the present study are similar to that reported in other studies measuring $\mathrm{P} 4$ in the whole milk in pregnant and non-pregnant cows $[33,34]$.

Cows having an additional CL had significantly higher concentrations of P4 than those having a single CL, and none of the cows having additional CLs lost their pregnancies from days 28 to 56. Our results are similar to those obtained in other studies [7, 31]. In these studies, cows with multiple corpora lutea had significantly higher plasma P4 concentrations than cows with a single CL either at day 7 after AI or during the early fetal period. On the other hand, Starbuck et al. [4] and Sartori et al. [31], reported that cows with 2 corpora lutea had P4 concentrations similar to those with a single CL. In our study, cows with additional CLs had a nonsignificantly lower $(0 / 5 v s$. 15/36) pregnancy loss than that of those with a single CL. Our results are in agreement with the results reported by Sartori et al. [31] who found a nonsignificant difference in the rate of pregnancy loss $(8 / 54$ vs. 2/12) from days $25-32$ to days $60-66$ between cows with single ovulation and those with multiple ovulation. However, other studies reported a significantly lower [22] or higher [4] pregnancy loss in cows with additional CLs. The difference among studies might be attributed to whether the additional CLs had been associated with twinning or not, whereas, twins increased the incidence of pregnancy loss [22]. At the same time Starbuck et al. [4] did not record how many cows with multiple CLs had multiple embryos at the initial examination at week 5 of gestation. In our study, the population number was relatively small, and if it were larger, the significance level might have been reached.

In our study, there were no significant differences in the bPAG-1 concentrations at days 28 and 42 of gestation among cows with normal pregnancy and those with either LEM or EFM. Also, there was no relationship between bPAG-1 concentrations at days 28 and 42 with LEM and EFM, respectively. Similarly, Szenci et al. [12] did not find differences in bPAG-1 concentrations between cows with ongoing pregnancy and those with interrupted pregnancies before loss of the conceptus. On the other hand, by logistic regression analysis, cows with low $(<2.5 \mathrm{ng} / \mathrm{ml})$ or high $(>4 \mathrm{ng} / \mathrm{ml})$ bPAG-1 concentrations at day 35 of gestation were 10 and 6.8 times more likely to suffer from fetal death, respectively [5]. About $63 \%$ of LEMs and EFMs could be predicted by measurement of bPSPB at days 30 to 36 after AI, and the prediction rate increased to $95 \%$ when the bPSPB was combined with low P4 level [14]. The difference in bPAG-1 profile prior to pregnancy loss among studies may point to different underlying mechanisms for pregnancy failure in the different experiments.

NO is produced by a variety of tissues including the uterus and placenta [35]. In our study, no significant differences were found in the level of NO between the pregnant and nonpregnant cows at days 28, 42 and 56 after AI, indicating that the placenta contributed a little to plasma NO in the pregnant cows during the study periods. This explanation is supported by the finding of a recent study in which the expression of NOS of the uteroplacental unit increased during the middle of bovine pregnancy [35]. In pregnant ewes, blood NO concentrations expressed a biphasic pattern, with the concentrations significantly increased compared with nonpregnant values at days 40 to 69 of gestation, and returned to the levels of nonpregnant concentrations from days 70 to 100 and again significantly increased until lambing [36]. This may indicate a difference in the profile of NO between the two species. Our interesting finding was the significant difference in the level of NO at day 28 between cows with LEM and cows with normal pregnancy. In addition, by logistic regression analysis, there was a significant association between serum NO concentrations at day 28 of pregnancy and the occurrence of LEM by day 42 . Cows with LEMs in the present study might have suffered from subclinical endometritis before or after breeding. In a recent study [37], the development of subclinical endometritis was observed in $22 \%$ of cows 4 hours following AI. Cows with subclinical endometritis had a significantly higher blood concentration of NO than that in healthy cows [38], and the plasma concentrations of NO were significantly higher in aborted ewes than that in healthy controls [39]. Bacterial products and endogenous mediators of subclinical endometritis, such as prostaglandins, NO, reactive oxygen species and cytokines, can detrimentally affect the quality of the oocyte. The affected oocytes may be able to undergo fertilization and cleavage but may have impaired developmental potential. In addition, both bacterial products and endogenous inflammatory mediators may affect embryo development and interrupt an established pregnancy [40]. The nonsignificant relationship between NO concentrations at days 28 and 42 and occurrence of EFM may indicate that the cause underlying the EFM might be different from that underlying LEM.

Since the number of cows with pregnancy losses in the present study was small, the result concerning the relationship between NO and LEM is preliminary and further studies using a larger number of cows with pregnancy losses are required. In conclusion, measurement of blood NO at day 28 of pregnancy might help to predict the outcome of pregnancy by day 42 in dairy cows.

\section{Acknowledgments}

This study was partly supported by the Hungarian Association for Buiatrics. The authors wish to thank László Takács, Imre Élö, Szilvia Szabó, György Erdélyi, Ernő Pál and Edith Csuka for their technical assistances during the experiment. The authors gratefully acknowledge Mrs Laura Schoofs and Najia Chahiba for their help with the PAG assay. 


\section{References}

1. De Vries A. Economic value of pregnancy in dairy cattle. J Dairy Sci 2006; 89: 3876 3885. [Medline] [CrossRef]

2. Whitlock BK, Maxwell HS. Pregnancy-associated glycoproteins and pregnancy wastage in cattle. Theriogenology 2008; 70: 550-559. [Medline] [CrossRef]

3. López-Gatius F. Factors of a noninfectious nature affecting fertility after artificial insemination in lactating dairy cows. A review. Theriogenology 2012; 77: 1029-1041. [Medline] [CrossRef]

4. Starbuck MJ, Dailey RA, Inskeep EK. Factors affecting retention of early pregnancy in dairy cattle. Anim Reprod Sci 2004; 84: 27-39. [Medline] [CrossRef]

5. López-Gatius F, Hunter RH, Garbayo JM, Santolaria P, Yániz J, Serrano B, Ayad A, de Sousa NM, Beckers JF. Plasma concentrations of pregnancy-associated glycoprotein-1 (PAG-1) in high producing dairy cows suffering early fetal loss during the warm season. Theriogenology 2007; 67: 1324-1330. [Medline] [CrossRef]

6. Humblot F, Camous S, Martal J, Charlery J, Jeanguyot N, Thibier M, Sasser RG. Pregnancy-specific protein $\mathrm{B}$, progesterone concentrations and embryonic mortality during early pregnancy in dairy cows. J Reprod Fertil 1988; 83: 215-223. [Medline] [CrossRef]

7. Bech-Sàbat G, López-Gatius F, Yániz JL, García-Ispierto I, Santolaria P, Serrano B, Sulon J, de Sousa NM, Beckers JF. Factors affecting plasma progesterone in the early fetal period in high producing dairy cows. Theriogenology 2008; 69: 426-432. [Medline] [CrossRef]

8. Wooding FB, Roberts RM, Green JA. Light and electron microscope immunocytochemical studies of the distribution of pregnancy associated glycoproteins (PAGs) throughout pregnancy in the cow: possible functional implications. Placenta 2005; 26: 807-827. [Medline] [CrossRef]

9. Zoli AP, Guilbault LA, Delahaut P, Ortiz WB, Beckers JF. Radioimmunoassay of a bovine pregnancy-associated glycoprotein in serum: its application for pregnancy diagnosis. Biol Reprod 1992; 46: 83-92. [Medline] [CrossRef]

10. Breukelman SP, Perényi Z, Taverne MAM, Jonker H, van der Weijden GC, Vos PLAM, de Ruigh L, Dieleman SJ, Beckers JF, Szenci O. Characterisation of pregnancy losses after embryo transfer by measuring plasma progesterone and bovine pregnancyassociated glycoprotein-1 concentrations. Vet J 2012; 194: 71-76. [Medline] [CrossRef]

11. Semambo DK, Eckersall PD, Sasser RG, Ayliffe TR. Pregnancy-specific protein B and progesterone in monitoring viability of the embryo in early pregnancy in the cow after experimental infection with Actinomyces pyogenes. Theriogenology 1992; 37: 741-748. [Medline] [CrossRef]

12. Szenci O, Humblot P, Beckers JF, Sasser G, Sulon J, Baltusen R, Varga J, Bajesy CA, Taverne MA. Plasma profiles of progesterone and conceptus proteins in cows with spontaneous embryonic/fetal mortality as diagnosed by ultrasonography. Vet $J 2000 ; 159$ : 287-290. [Medline] [CrossRef]

13. Szenci O, Beckers JF, Sulon J, Bevers MM, Börzsönyi L, Fodor L, Kovács F, Taverne MAM. Effect of induction of late embryonic mortality on plasma profiles of pregnancy associated glycoprotein 1 in heifers. Vet $J$ 2003; 165: 307-313. [Medline] [CrossRef]

14. Gábor G, Tóth F, Ozsvári L, Abonyi-Tóth Z, Sasser RG. Early detection of pregnancy and embryonic loss in dairy cattle by ELISA tests. Reprod Domest Anim 2007; 42: 633-636. [Medline] [CrossRef]

15. Knowles RG, Moncada S. Nitric oxide synthases in mammals. Biochem $J$ 1994; 298: 249-258. [Medline]

16. Korzekwa A, Woclawek-Potocka I, Okuda K, Acosta TJ, Skarzynski DJ. Nitric oxides in bovine corpus luteum: possible mechanisms of action in luteolysis. Anim Sci J 2007; 78: 233-242. [CrossRef]

17. Groebner AE, Schulke KS, Bauersachs S, Wolf E, Meyer HHD, Ulbrich SE. Expression of inducible and endothelial nitric oxide synthase in the bovine endometrium during estrouscycle and early pregnancy. Reprod Domest Anim 2008; 43(Suppl.1): 12. [Medline]

18. Soto P, Natzke RP, Hansen PJ. Identification of possible mediators of embryonic mortality caused by mastitis: actions of lipopolysaccharide, prostaglandin F2 $\alpha$, and the nitric oxide generator, sodium nitroprusside dihydrate, on oocyte maturation and embryonic development in cattle. Am J Reprod Immunol 2003; 50: 263-272. [Medline] [CrossRef]

19. Bird IM, Zhang L, Magness RR. Possible mechanisms underlying pregnancy-induced changes in uterine artery endothelial function. Am J Physiol Regul Integr Comp Physiol
2003; 284: R245-R258. [Medline]

20. Ferguson JD, Galligan DT, Thomsen N. Principal descriptors of body condition score in Holstein cows. J Dairy Sci 1994; 77: 2695-2703. [Medline] [CrossRef]

21. Szenci O, Beckers JF, Humblot P, Sulon J, Sasser G, Taverne MAM, Varga J, Baltusen R, Schekk G. Comparison of ultrasonography, bovine pregnancy-specific protein $\mathrm{B}$, and bovine pregnancy-associated glycoprotein 1 tests for pregnancy detection in dairy cows. Theriogenology 1998; 50: 77-88. [Medline] [CrossRef]

22. López-Gatius F, Santolaria P, Yániz J, Rutllant J, López-Béjar M. Factors affecting pregnancy loss from gestation Day 38 to 90 in lactating dairy cows from a single herd. Theriogenology 2002; 57: 1251-1261. [Medline] [CrossRef]

23. Perényi ZS, Szenci O, Sulon J, Drion PV, Beckers JF. Comparison of the ability of three radioimmunoassay to detect pregnancy-associated glycoproteins in bovine plasma. Reprod Domest Anim 2002; 37: 100-104. [Medline] [CrossRef]

24. Perényi ZS, Szenci O, Drion PV, Banga-Mboko H, Sousa NM, EI Amiri B, Beckers JF. Aspartic proteinase members secreted by the ruminant placenta: specificity of three radioimmunoassay systems for the measurement of pregnancy-associated glycoproteins. Reprod Domest Anim 2002; 37: 324-329. [Medline] [CrossRef]

25. Green LC, Wagner DA, Glogowski J, Skipper PL, Wishnok JS, Tannenbaum SR. Analysis of nitrate, nitrite, and [15N]nitrate in biological fluids. Anal Biochem 1982; 126 131-138. [Medline] [CrossRef]

26. Hosmer DW, Lemeshow S. Applied Logistic Regression, John Wiley \& Sons, New York; 1989.

27. Fricke PM, Guenther JN, Wiltbank MC. Efficacy of decreasing the dose of GnRH used in a protocol for synchronization of ovulation and timed AI in lactating dairy cows. Theriogenology 1998; 50: 1275-1284. [Medline] [CrossRef]

28. Cartmill JA, El-Zarkouny SZ, Hensley BA, Lamb GC, Stevenson JS. Stage of cycle, incidence, and timing of ovulation, and pregnancy rates in dairy cattle after three timed breeding protocols. J Dairy Sci 2001; 84: 1051-1059. [Medline] [CrossRef]

29. Cartmill JA, El-Zarkouny SZ, Hensley BA, Rozell TG, Smith JF, Stevenson JS. An alternative AI breeding protocol for dairy cows exposed to elevated ambient temperature before or after calving or both. J Dairy Sci 2001; 84: 799-806. [Medline] [CrossRef]

30. Gümen A, Guenther JN, Wiltbank MC. Follicular size and response to Ovsynch versus detection of estrus in anovular and ovular lactating dairy cows. J Dairy Sci 2003; 86: 3184-3194. [Medline] [CrossRef]

31. Sartori R, Gümen A, Guenther JN, Souza AH, Caraviello DZ, Wiltbank MC. Comparison of artificial insemination versus embryo transfer in lactating dairy cows. Theriogenology 2006; 65: 1311-1321. [Medline] [CrossRef]

32. Gábor G, Tóth F, Ozsvári L, Abonyi-Tóth Z, Sasser R. Factors influencing pregnancy rate and late embryonic loss in dairy cattle. Reprod Domest Anim 2008; 43: 53-58. [Medline]

33. Bulman DC, Lamming GE. Milk progesterone levels in relation to conception, repea breeding and factors influencing acyclicity in dairy cows. J Reprod Fertil 1978; 54 447-458. [Medline] [CrossRef]

34. Cox NM, Thompson FN, Culver DH. Milk progesterone to predict reproductive status in a commercial dairy herd. J Dairy Sci 1978; 61: 1616-1621. [Medline] [CrossRef]

35. Hayashi KG, Hosoe M, Takahashi T. Placental expression and localization of endothelin-1 system and nitric oxide synthases during bovine pregnancy. Anim Reprod Sci 2012 134: 150-157. [Medline] [CrossRef]

36. Vonnahme KA, Wilson ME, Li Y, Rupnow HL, Phernetton TM, Ford SP, Magness RR. Circulating levels of nitric oxide and vascular endothelial growth factor throughout ovine pregnancy. J Physiol 2005; 565: 101-109. [Medline] [CrossRef]

37. Kaufmann TB, Drillich M, Tenhagen BA, Forderung D, Heuwieser W. Prevalence of bovine subclinical endometritis $4 \mathrm{~h}$ after insemination and its effects on first service conception rate. Theriogenology 2009; 71: 385-391. [Medline] [CrossRef]

38. Li D, Liu Y, Li Y, Lv Y, Pei X, Guo D. Significance of nitric oxide concentration in plasma and uterine secretes with puerperal endometritis in dairy cows. Vet Res Commun 2010; 34: 315-321. [Medline] [CrossRef]

39. Aytekin I, Aypak SU. Levels of selected minerals, nitric oxide, and vitamins in aborted Sakis sheep raised under semitropical conditions. Trop Anim Health Prod 2011; 43 511-514. [Medline] [CrossRef]

40. Gilbert RO. The effects of endometritis on the establishment of pregnancy in cattle. Reprod Fertil Dev 2011; 24: 252-257. [Medline] [CrossRef] 